\title{
Mathematical Reasoning: Bibliometric Analysis of the Literature
}

\section{Halil Çoban ${ }^{1}$ I Erdoğan Tezci ${ }^{2}$}

\author{
${ }^{1}$ Dr., Ministry of Education, \\ Manisa/Turkey \\ ORCID: 0000-0001-6807-1380 \\ E-Mail: \\ cobanhalil@hotmail.com \\ 2 Prof. Dr., Balikesir University, \\ Balikesir/Turkey \\ ORCID: 0000-0003-2055-0192 \\ E-Mail: \\ etezci@balikesir.edu.tr
}

Corresponding Author:

Halil Çoban

\section{an}

Key Words: Bibliometric Analysis, Mathematical Reasoning, Bibliometric Mapping.

January 2022

Volume:19

Issue: 45

DOI: $10.26466 / /$ opusjsr.1062867

Citation:

Çoban, H. and Tezci, E. (2022).

Mathematical reasoning: Bibliometric analysis of the literature . OPUS- Journal of Society Research, 19(45), 88-102. Öz \begin{abstract}
have contributed to the field in recent years.
Abstract

The aim of this study is to examine the literature on mathematical reasoning. In the WoS (Web of Science) database, 545 publications published in different journals until January 2021 were analyzed by using the bibliometric analysis method. The most used keywords by the authors, bibliographic couplings, and common citations were analyzed and visualized through the Vosviewer software. As a result of the analyses, the most common keywords used by the authors in publications related to the field were found to be "mathematical reasoning", "problem solving", and "mathematical thinking". The prominent universities in the publications in the field of mathematical reasoning were determined as "Brigham Young University", "Michigan University", and "Alicante University". In addition, the most influential journals in the field were "Journal for Research in Mathematics Education", "Educational Studies in Mathematics", and "Journal of Educational Psychology". The most influential authors in the field were "Schoenfeld, A. H.", "Carpenter T. P.", and "Geary, D. C.". Finally, when the publications in the field were analyzed, the prominent countries were found to be the USA, Turkey, and Sweden; and Indonesia and People's Republic of China stand out as the origin of publications that
\end{abstract}

Bu çalışmanın amacı matematiksel muhakeme ile ilgili literatürdeki yayınları incelemektir. WoS (Web of Science) veri tabanında Ocak 2021'e kadar farklı dergilerde yayınlanmıs olan 545 yayın bibliyometrik analiz yöntemi ile analiz edilmiştir. Yazarlar tarafindan ortak olarak en çok kullanılan anahtar kelimeler, bibliyografik eşleşmeler ve ortak atıflar Vosviewer yazılımı aracıllŏ̆ıla analiz edilerek görselleştirilmiştir. Yapılan analizler neticesinde yazarlarm alana ilişkin yayınlarda en çok kullandiklar anahtar kelimelerin "mathematical reasoning", "problem solving" ve "mathematical thinking" olduğu belirlenmiştir. Matematiksel muhakeme alanında yapılan yayınlarda öne çıkan üniversiteler "Brigham Young University", "Michigan University" ve "Alicante University" olarak belirlenmiştir. Ayrıca alana ilişkin yayınlarm yer aldığı en etkili dergilerin "Journal for Research in Mathematics Education", "Educational Studies in Mathematics" ve "Journal of Educational Psychology" olduğu görülmüştür. Alanda en etkili yazarlar Schoenfeld, A.H., Carpenter T.P. ve Geary, D.C. olarak tespit edilmiştir. Ayrıca alanda yapılan yayınlar analiz edildiğinde öne çıkan ülkelerin $A B D$, Türkiye ve İsviçre olduğu son yıllarda alana katkı sağlayan yayınların menşei olarak Endonezya ve Çin Halk Cumhuriyeti ülkelerin öne çıktığı görülmektedir.

Anahtar Kelimeler: Bibliyometrik Analiz, Matematiksel Muhakeme, Matematiksel Akıl Yürütme, Bibliyometrik Haritalama. 


\section{Introduction}

The reasoning skill, which is one of the basic mathematical competencies, is considered extremely important both in teaching mathematics and making sense of mathematics (Sukirwan, Darhim, \& Herman, 2018). The NCTM defines the purpose of learning mathematics as learning to communicate, learning to reason, and learning to solve problems (NCTM, 2000). Reasoning skill that is among the purposes of learning mathematics includes many mathematical skills such as making mathematical predictions, presenting mathematical information in different ways, developing mathematical discussions, and making generalizations (MEB, 2015; NCTM, 2000). From this perspective, mathematical reasoning exists in every aspect of mathematics and is very vital in the teaching and learning process of mathematics. However, it should not be forgotten that the development of mathematical reasoning skills cannot be independent of mathematics learning (Bragg, Herbert, Loong, Vale \& Widjaja, 2016; Lestari \& Jailani, 2018).

Different definitions of mathematical reasoning can be encountered in the literature. One of the most used definitions sees mathematical reasoning as a mathematical ability that students need to understand mathematics (Ball \& Bass, 2003), while another definition is expressed as thinking adopted until reaching a conclusion by generating hypotheses in problem solving (Lithner, 2008). As can be deduced from these definitions, mathematical reasoning is one of the important factors affecting mathematics achievement (Ball \& Bass, 2003; Umay, 2003). Individuals with mathematical reasoning skills are expected to make logical inferences, use mathematical relations and models, justify solutions while solving a problem, and generalize the solution to new situations (Kadarisma, Nurjaman, Sari \& Amelia, 2019; Kurnaz, 2018). The increasing interest in mathematical reasoning in recent years is closely related to the understanding of the importance of mathematical reasoning in teaching and learning mathematics (Lestari \& Jailani, 2018).
This study aimed to examine the publications related to mathematical reasoning according to their specific characteristics. For this purpose, the bibliometric analysis method was used in the research, which allows to follow the historical trends of the publications, to follow the developments in the field, and to reveal the specific features of the field (Cobo, LópezHerrera, Herrera-Viedma \& Herrera, 2011). Thanks to bibliometric research, the publications can be analyzed with statistical and mathematical methods, and the results related to the quality of the publications can be revealed with the findings (Al, Soydal \& Yalçın, 2010). Bibliometric methods are used for two purposes: performance analysis and scientific mapping (Noyons, Moed \& Van Raan, 1999). Performance analysis aims to evaluate the activities of countries, universities, faculties and departments and the impact of their activities (Cobo et al., 2011). In performance analysis, the effectiveness, the impact, and the joint effectiveness of publications are determined. The effectiveness of the publications is revealed by the number of publications in a certain period, the impact of the publications is revealed by calculating the number of times the publication is cited by others, and the joint effectiveness is revealed by calculating the number of publications jointly published with other people (Noyons et al., 1999). Scientific mapping is aimed at revealing the structure, change, and subdomains of the field (Cobo et al., 2011). Scientific mapping is clusters of cognitively related keywords that emerge as a result of the analysis of synonyms (Noyons et al., 1999). These revealed keyword clusters form the subdomains of the field, and the changes that occur in these subdomains reveal the trends of the field (Noyons et al., 1999).

The database from which bibliographic data is obtained in this study is Web of Science (WoS). The WoS database, especially in the field of social sciences, contains a large number of journals with high impact factors and provides conveniences for researchers when analyzing.

\section{Method}

The Purpose and the Importance of the Research 
The aim of this study is to examine the publications in the field of mathematical reasoning by considering certain features and criteria and to reveal the dynamics of the field and the performances of scientific actors (countries, universities, institutions, etc.). The study is important in that it is the first in the national literature in this field.

\section{The Process of the Research}

In the search made in the WoS database, the studies carried out until January 2021 were examined. While searching, the advanced search feature was used, and the keywords "mathematical reasoning" and "mathematical thinking" were searched in the titles without time restrictions. As a result of the search, 580 publications were reached, filtered according to the types of publications, and 545 publications formed the analysis unit. The distribution of the publications examined in the research by genres is given in Table 1 and the distribution by years is given in Table 2.

Table 1. Distribution of Publications by Types

\begin{tabular}{lll}
\hline Publication types & Number of Publications Percentage \\
\hline $\begin{array}{l}\text { Journal articles } \\
\begin{array}{l}\text { Proceedings and } \\
\text { abstracts }\end{array}\end{array}$ & 298 & 55 \\
$\begin{array}{l}\text { Books and book } \\
\text { chapters }\end{array}$ & 205 & 38 \\
\hline
\end{tabular}

In Table 1, the distribution of the publications that make up the analysis unit according to their types is given. Accordingly, 55\% of the publications that make up the analysis unit consist of journal articles, 38\% of proceedings, and $7 \%$ of books and book chapters.

Table 2. Distribution of Publications by Years

\begin{tabular}{lll}
\hline Publication Years & Number of Publications & Percentage \\
\hline $\mathbf{1 9 8 0 - 1 9 8 5}$ & 17 & 3 \\
$\mathbf{1 9 8 6 - 1 9 9 0}$ & 24 & 4 \\
$\mathbf{1 9 9 1 - 1 9 9 5}$ & 21 & 4 \\
$\mathbf{1 9 9 6 - 2 0 0 0}$ & 34 & 6 \\
$\mathbf{2 0 0 1 - 2 0 0 5}$ & 41 & 7 \\
$\mathbf{2 0 0 6 - 2 0 1 0}$ & 86 & 15 \\
$\mathbf{2 0 1 1 - 2 0 1 5}$ & 134 & 23 \\
$\mathbf{2 0 1 6 - 2 0 2 1}$ & 223 & 38 \\
\hline
\end{tabular}

In Table 2, the distribution of the publications in the field of mathematical reasoning by years is given. The publications in the last 5 years constitute $38 \%$ of all publications. This can be considered as an indication that publications on mathematical reasoning and mathematical thinking have gained importance in recent years.

\section{Data Analysis}

In the study, the publications that make up the data set were analyzed in terms of their specific characteristics (publication year, author, subject, source, references, etc.) with the bibliometric analysis method based on mathematics and statistics (Hoffman \& Holbrook, 1993). The threshold value was used to ensure that the data have a regular appearance and facilitate interpretation (White \& McCain, 1998). The VOSviewer software was used to analyze and visualize the relationships between authors, sources, countries, keywords, and citations. Analyses of the keywords used by the authors, bibliographic couplings (countries, universities, authors), and common citations (authors, journals, references) were made using the data set via the VOSviewer software. Bibliographic coupling occurs as a result of citing the same publication from two different sources (Garfield, 1988). Co-citation occurs when two different publications are cited in one source (Garfield, 1988). In this case, while bibliographic coupling power does not change over time, common citation power can change over time as the number of publications will increase. The concept of bibliographic coupling and co-citation is shown in Figure 1. 


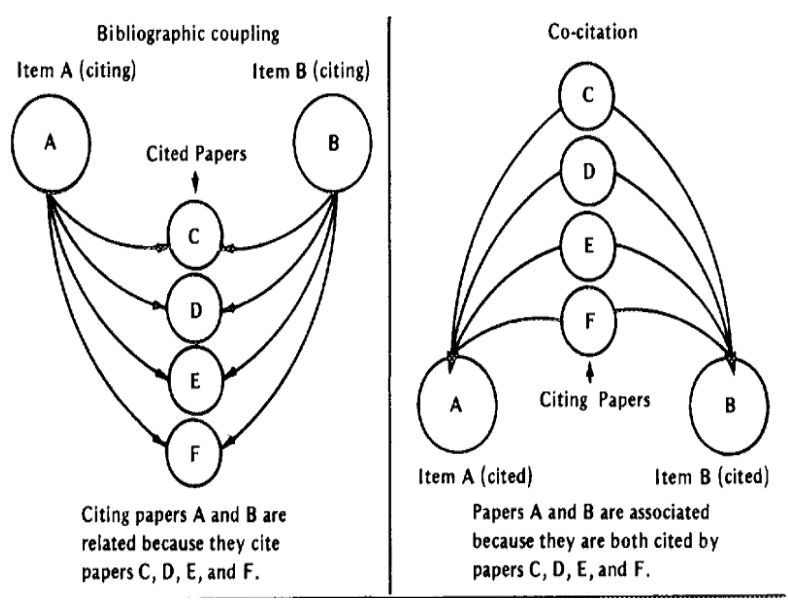

Figure 1. Bibliographic coupling and co-citation (Garfield, 1988).

Attention was paid to some features that should be considered while interpreting the images that appear in the VOSviewer software. The similarity of colors and the formation of lines in the image of the citation link is an indication that the interconnected powers are more intense than the others. In the density image, the colors reveal the most connected items among the analyzed items. As the color of links goes towards red, their connection with others increases. In addition, the closeness of the circles to each other is directly proportional to the strength of the connection powers. Each color formed is an indication that a different set has emerged.

\section{Findings}

\section{Common Occurrences of Keywords}

Common occurrences of keywords used in publications are shown in Figure 2. Words used in at least 5 publications as a threshold value were included in the analysis. Of the 933, 20 words met this threshold value. The total weight of links between all keywords was calculated. Accordingly, "mathematical reasoning" was determined as the most used common keyword in the field with a total weight (TLS) value of 23 of 54 occurrences and links. After the keyword "mathematical reasoning", the words with the highest TLS value were determined as "problem solving $(13 ; 15)$ " and "mathematical thinking (49; $14)^{\prime \prime}$, with the first number in parentheses being the number of occurrences and the second number being the TLS value. The common occurrences of the keywords used by the authors are shown in Figure 2.

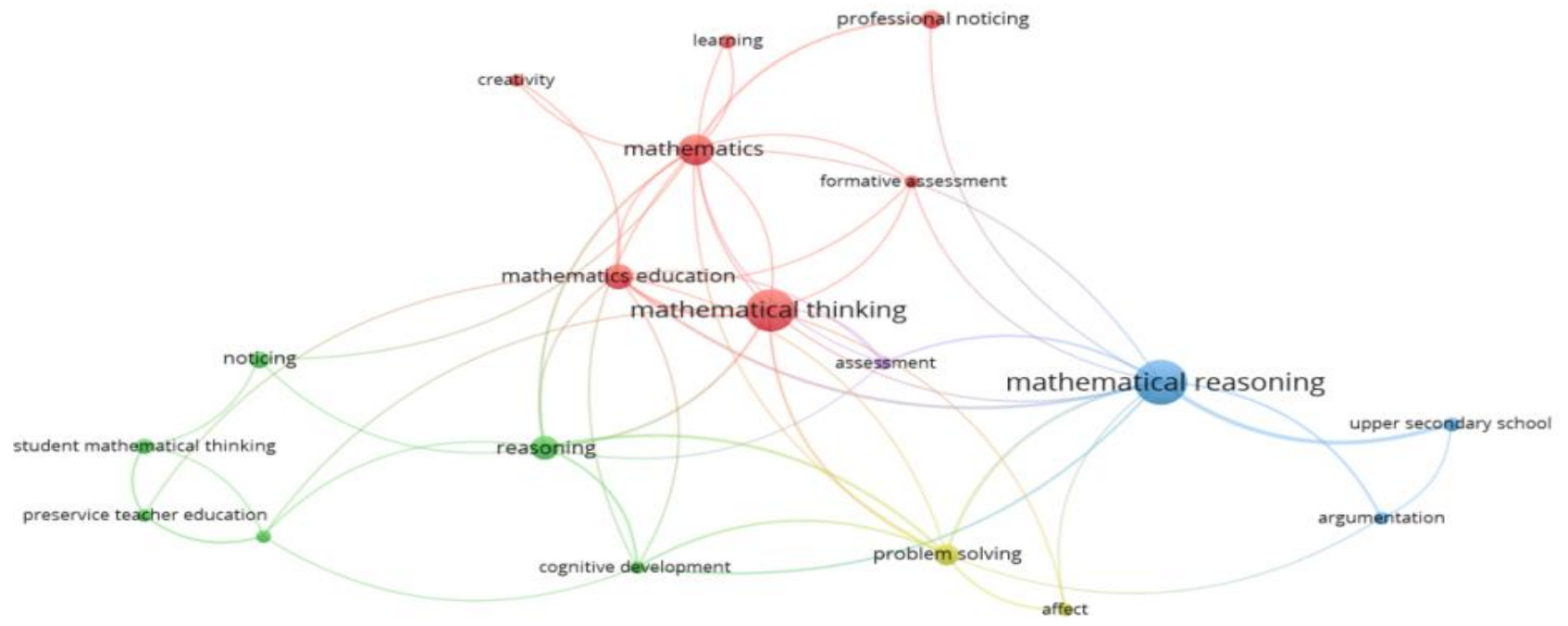

Figure 2. Common occurrences of keywords. 
As seen in Figure 2, the size of the circles and the number of common occurrences of keywords are directly proportional to each other. In addition, the keywords related to each other are represented by different colors. The words "Mathematical reasoning", "Mathematical thinking" and "mathematics" can be expressed as the words that have the most connections with other words. The formation of clusters is shown in Figure 3.

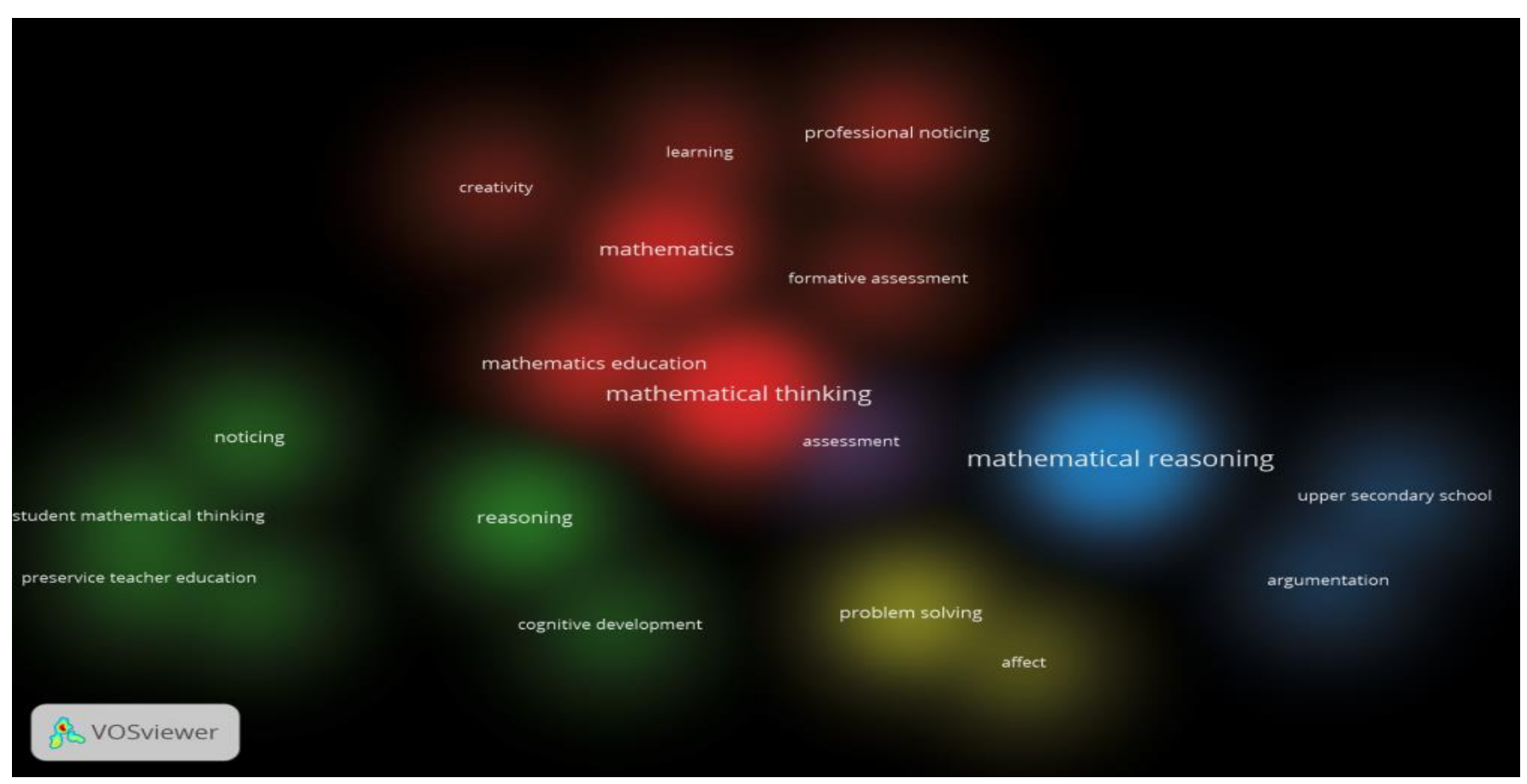

Figure 3. Clusters of keywords.

In Figure 3, 5 different clusters are represented by 5 different colors and the keywords are grouped. On one hand, one of the clusters is composed of the words "mathematical reasoning (54; 23)", "argumentation $(5 ; 4)$ " and "upper secondary school $(6 ; 7)$ " with the first number to show the number of occurrences and the second to show TLS value. On the other hand, another cluster is composed of the words "mathematical thinking $(49 ; 14)$ ", "mathematics education (18; 14)", "mathematics (25; 14)", "formative assessment $(5 ; 4)$ ", "creativity $(5 ; 2)$ ", "learning (6; $2)^{\prime \prime}$ and "professional noticing $(9 ; 3)$ ".

\section{Co-citation analysis of authors}

When the number of co-citations of the authors was examined, the threshold value was determined as those who were co-cited at least 30 times out of 8327 authors. 28 of the authors provided this threshold value. As a result of the co-citation analysis, the first three of the most influential authors in the field are ranked according to TLS value, with the first number in parentheses being the number of citations and the second number being the TLS value, Schoenfeld, A. H. (83; 1046), Carpenter T. P. (75; 1042), and Geary, D. C. $(36 ; 1002)$. The values that emerged as a result of the co-citation analysis of the 
authors and their maps related to each other are given in Figure 4 and Figure 5.

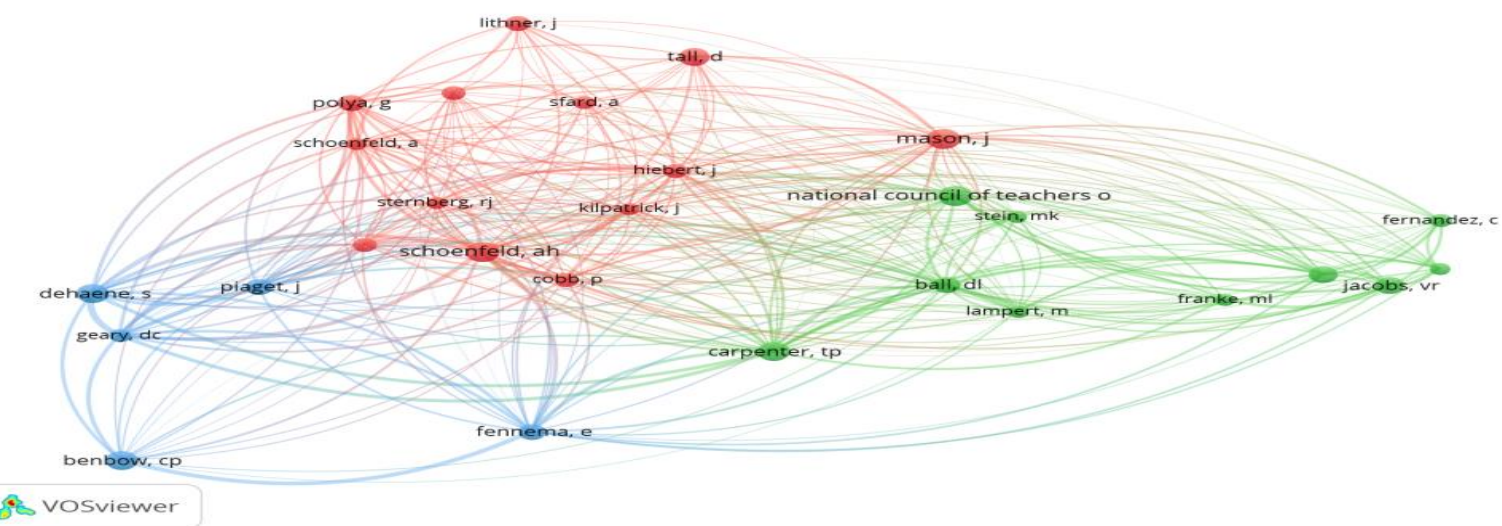

Figure 4. Co-citation links of authors.

In Figure 4, the authors who are most related to each other are shown in 3 different groups and in 3 different colors.

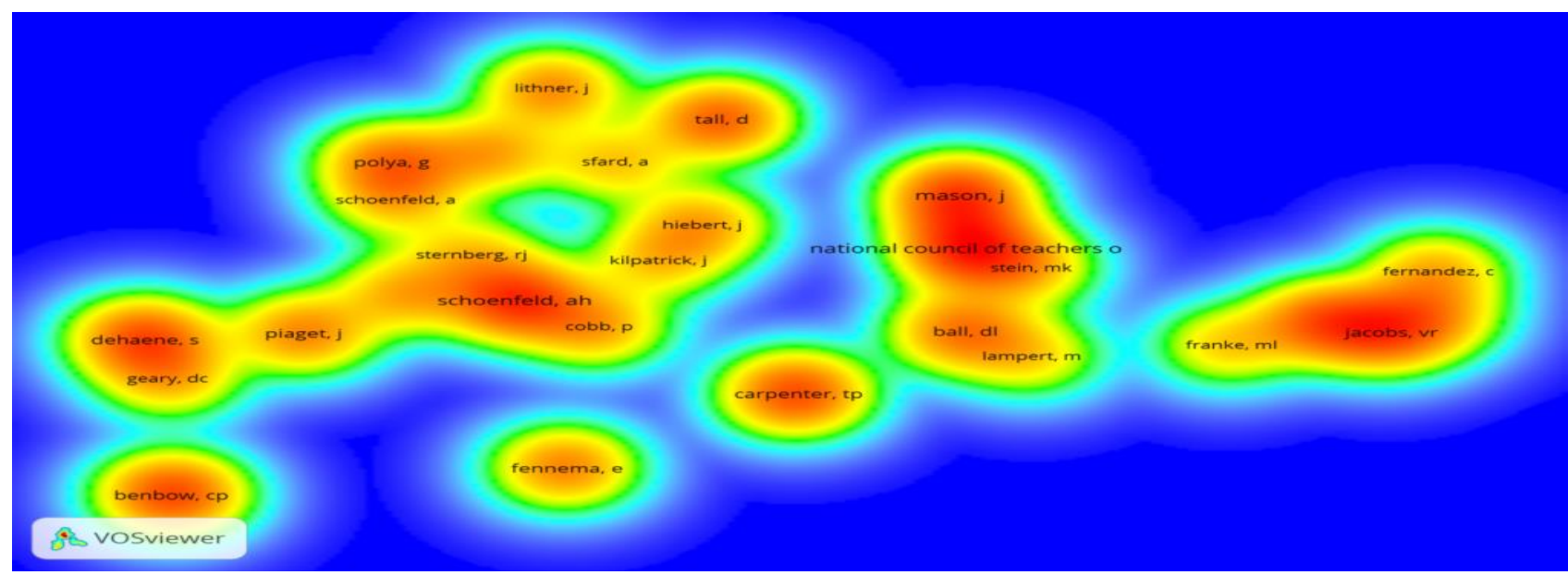

Figure 5. Authors' co-citation review.

As seen in Figure 5, the colors that the authors have are in a transition towards red as the number of their common citations increases. Accordingly, the authors of NCTM (88), Schoenfeld (83), Mason (81), Benbow (77), Carpenter (75), Dehaene (73) stand out as the authors with the highest number of co-citations.

\section{Co-citation analysis of journals}

When the co-citation numbers of the sources published in the field are examined, those with at least 50 citations out of 6924 co-cited sources were included in the analysis. From these sources, 28 sources providing the threshold value were determined. The total weight (TLS) of each source's citations and links to other sources was calculated. Accordingly, as a result of the common citation analysis, the first three of the most influential sources in the field, the first number in parentheses to give the number of citations and the second number to give the TLS value, respectively, were designated as "Journal for Research in Mathematics Education (453; 16904), "Educational Studies in Mathematics (469; 9130), and "Journal of Educational Psychology $(164 ; 9028)$ ". The values that emerged as a result of the co-citation analysis of the sources and the 
maps related to their relations with each other are given in Figure 6 and Figure 7.

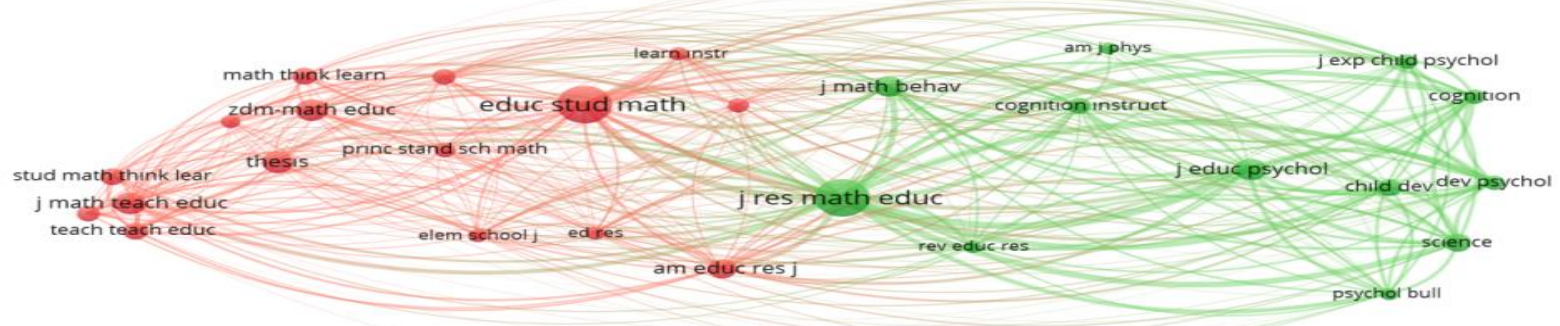

f vosviewer

Figure 6. Co-citation review of sources.

When Figure 6 is examined, the sources that are connected with each other are represented by two different colors in two different clusters.

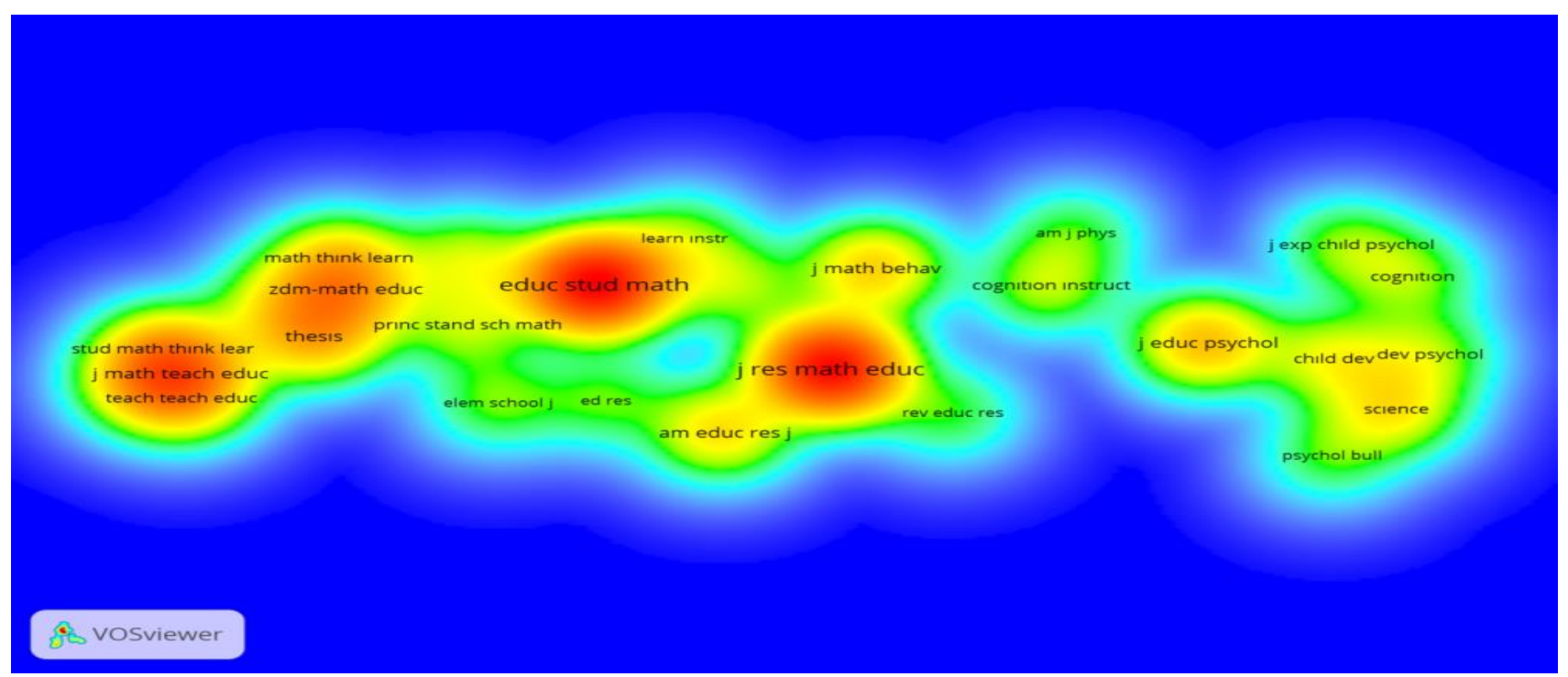

Figure 7.Co-citation review of sources.

As seen in Figure 7, the colors of the sources have different colors from green to red. The colors of the sources with the most common references are close to red. Accordingly, the prominent sources in the field are "Educational Studies in Mathematics (469)", "Journal for Research in
Mathematics Education (453)", and "Journal of Mathematics Teacher Education (167)".

\section{Co-citation analysis of references}

When the co-citation numbers of the references were examined, those with at least 10 co-citations out of 13521 co-cited references were included in 
the analysis. From these references, 33 publications providing the threshold value were identified. The total weight (TLS) of citations for each publication and its links to other sources was calculated. Accordingly, as a result of the common citation analysis, the first three of the most influential publications in the field, the first number in parentheses to give the publication year, the second to give the number of citations, and the third number to give the TLS value, respectively, were "Jacobs, Lamb, \& Phillipp (2010; 41; 142)", “NCTM (2000; 36; 103)”, and "Fennema, Carpenter, Franke, Levi, Jacobs, \& Empson (1996; 16; 78)". The values that emerged as a result of the co-citation analysis of the references and the maps related to their relations with each other are given in Figure 8 and Figure 9

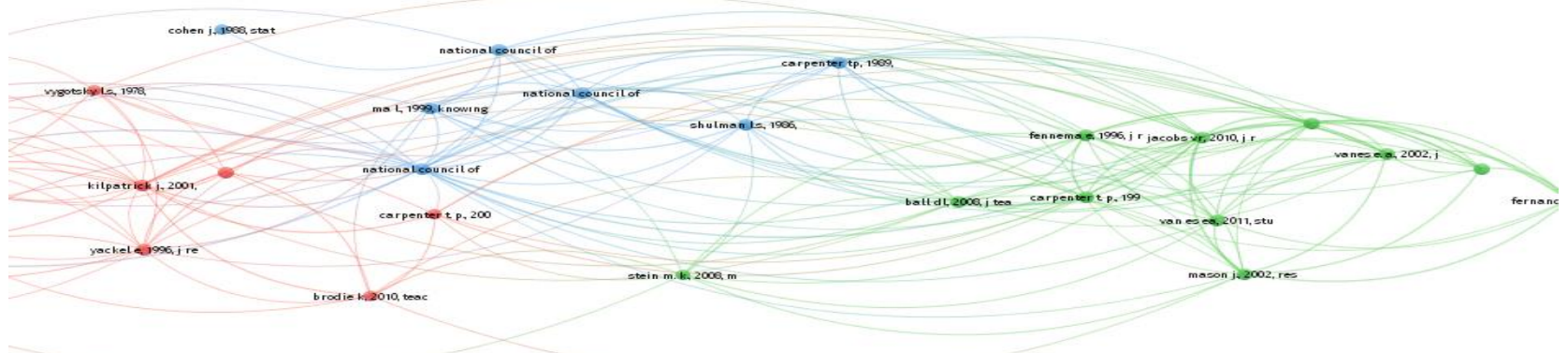

Figure 8.Co-citation analysis of references.

In Figure 8 , the references that are related to each other are represented by three different colors in three different clusters. The publications of the authors of Jacobs et al. (2010) and NCTM
(2000) come to the fore and there is a dense network of relations with other authors.

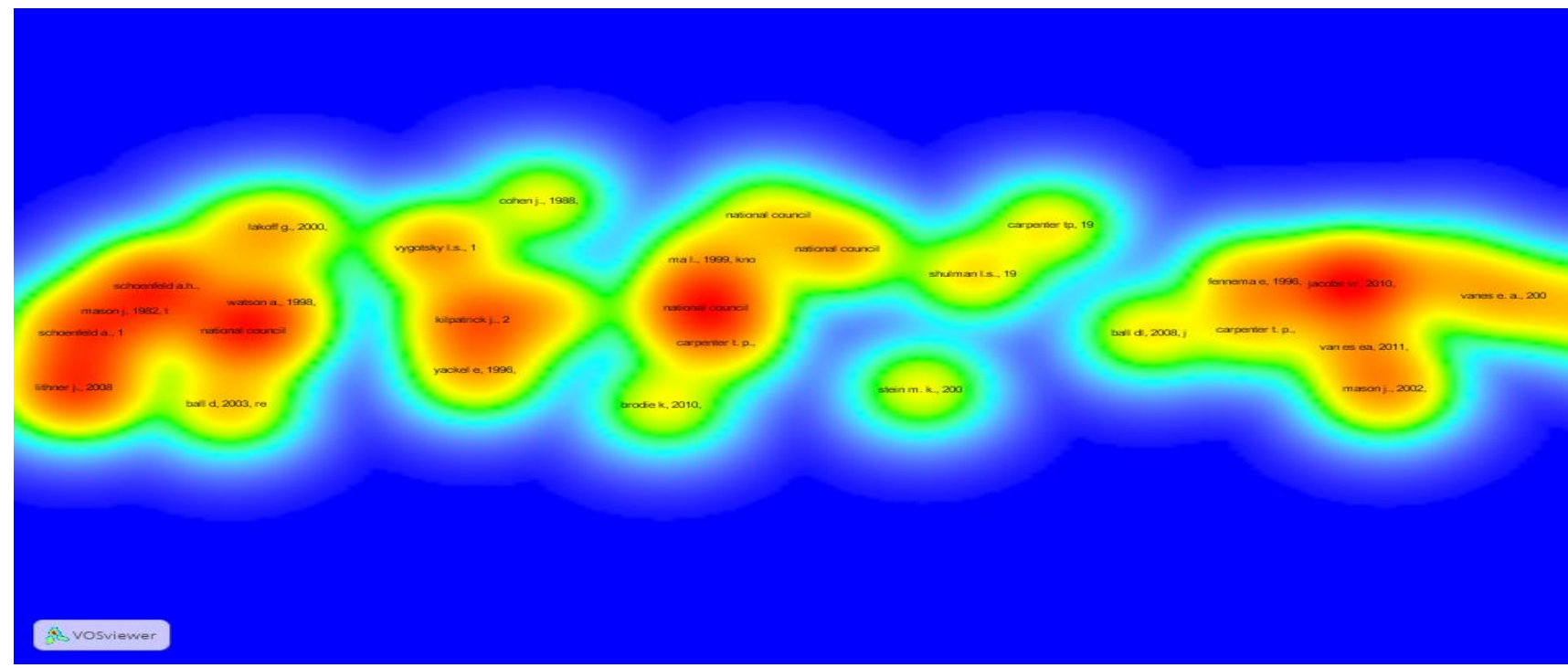

Figure 9.Co-citation analysis of references. 
As seen in the cluster density image given in Figure 9, the references with intense redness are the publications with the most common citations. Accordingly, among the prominent publications in the field, the ones with the highest number of common citations were publications that belong to the authors as "Jacobs et al. (2010; 41)", "NCTM (2000; 34)", "Lithner $(2008 ; 32)$ ", and "Schoenfeld $(1992 ; 28) "$ the first number in parentheses being the year of publication and the second number being the number of joint citations.

\section{Bibliographic couplings of countries}

The bibliographic couplings of the countries are shown in Figure 10 and Figure 11. Countries with at least 10 publications were included in the analysis. Of the 54 countries, 14 met the threshold value. The TLS value, which is the result of the connections of each country with other countries, was calculated. USA ranked first with 143 publications, 3856 citations, and 3008 TLS values. The number of publications, number of citations, and TLS value of the first 5 countries that are bibliographically coupled are given in Table 3 .

\section{Table 3. Bibliographic Couplings of Countries}

\begin{tabular}{llll}
\hline Countries & $\begin{array}{l}\text { Number of } \\
\text { publications }\end{array}$ & Number of citations & TLS \\
\hline ABD & 143 & 3856 & 3008 \\
Turkey & 27 & 73 & 1206 \\
Sweden & 20 & 104 & 963 \\
Spain & 25 & 66 & 890 \\
Australia & 21 & 198 & 859 \\
\hline
\end{tabular}

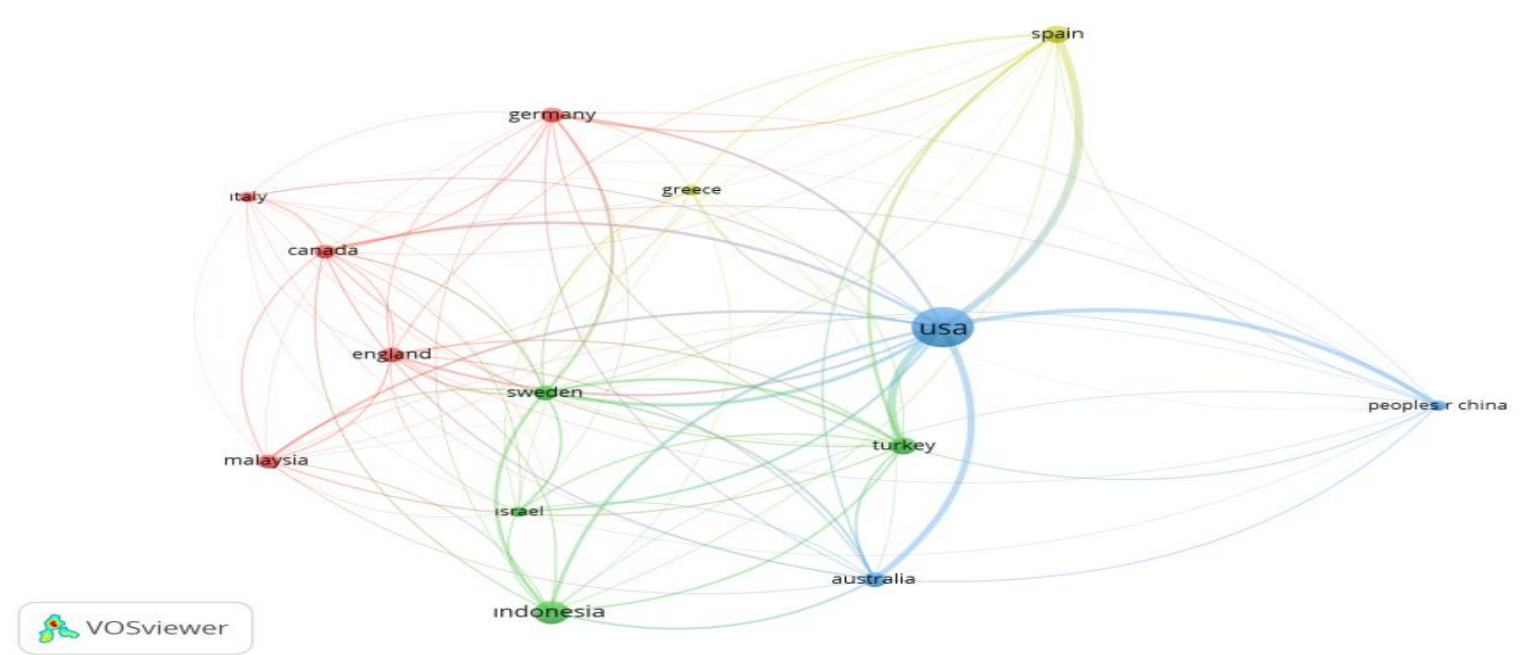

Figure 10.Bibliographic couplings of countries.

In Figure 10, bibliographically coupled and related countries are gathered in 4 different clusters and represented by 4 different colors. The USA is at the forefront as the country with the most connectivity. 


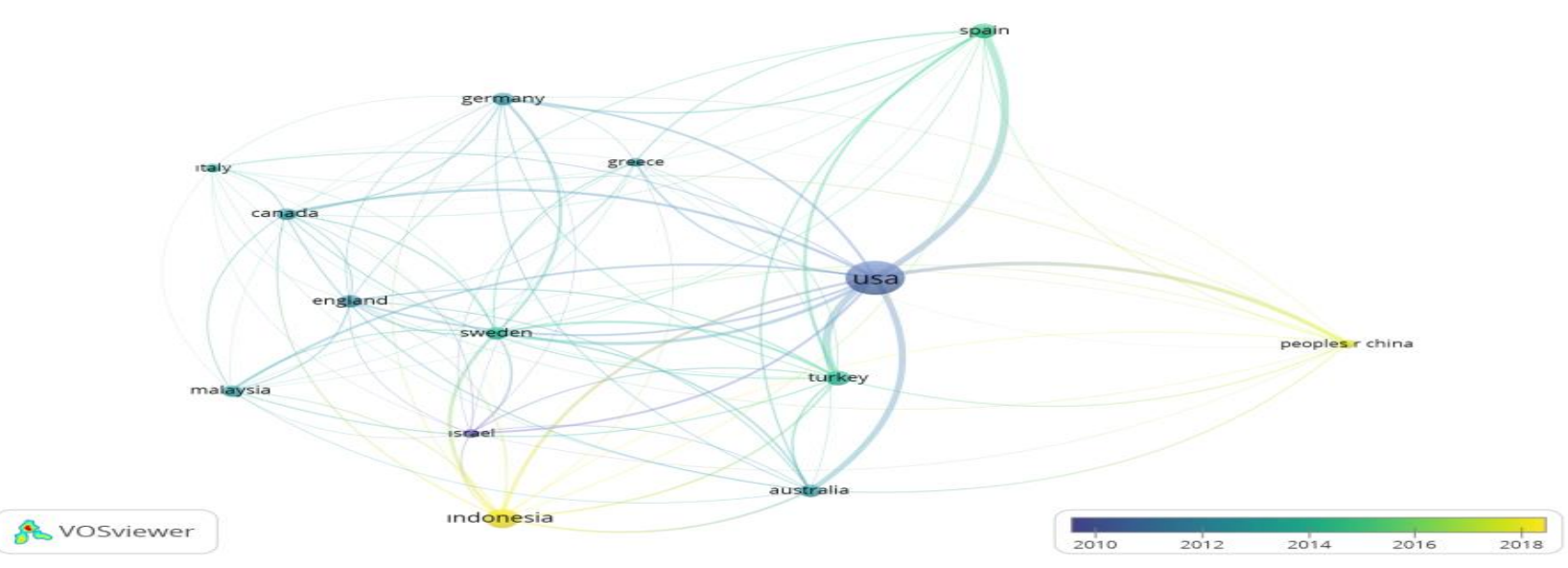

Figure 11.Examination of the publications according to the years that the countries published.

In Figure 11, the relations of the countries that publish in the field and coupled bibliographically with the years of publication are represented by different colors. Accordingly, Indonesia and the People's Republic of China are the countries that have published most in the field in recent years.

\section{Bibliographic couplings of institutions}

The results of the bibliographic coupling analysis regarding the institutions of the authors publishing in the field are visualized in Figure 12 and Figure 13. Institutions with at least 5 publications out of 471 were selected as the threshold value and 17 institutions that passed this threshold were included in the analysis. Accordingly, "Brigham Young University", one of the universities in the USA, took the first place with 7 publications, 22 citations, and 669 TLS value. The top five universities are presented in Table 4 with their publication numbers, citation numbers and TLS values.

Table 4. Information on Bibliographic Couplings of Institutions

\begin{tabular}{llll}
\hline Institutions & $\begin{array}{l}\text { Number of } \\
\text { publications }\end{array}$ & $\begin{array}{l}\text { Number of } \\
\text { citations }\end{array}$ & TLS \\
\hline Brigham Young Univ. & 7 & 22 & 669 \\
Michigan Technol. Univ. & 5 & 31 & 667 \\
Alicante Univ. & 10 & 43 & 616 \\
Seville Univ. & 6 & 15 & 455 \\
Michigan State Univ. & 7 & 91 & 363 \\
\hline
\end{tabular}

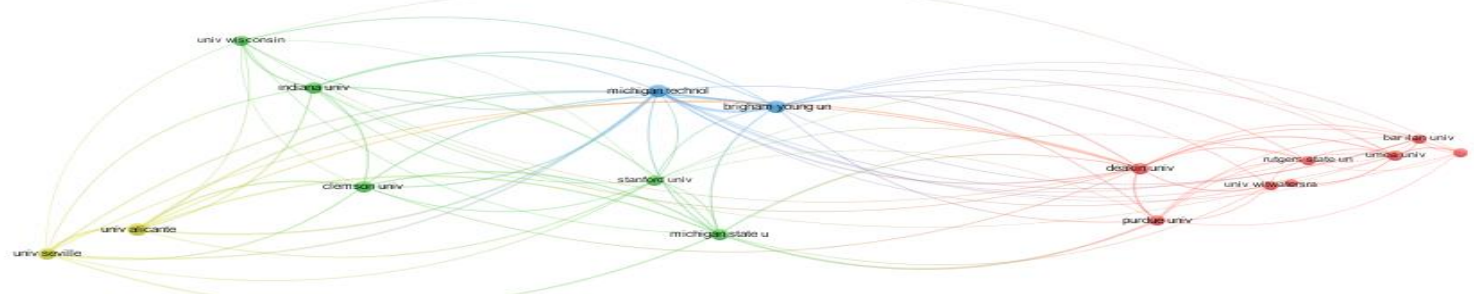

Figure 12.Bibliographic couplings of institutions. 
As seen in Figure 12, the publications made in the field are in 4 different clusters according to their bibliographically coupled institutions and they are represented by 4 different colors.

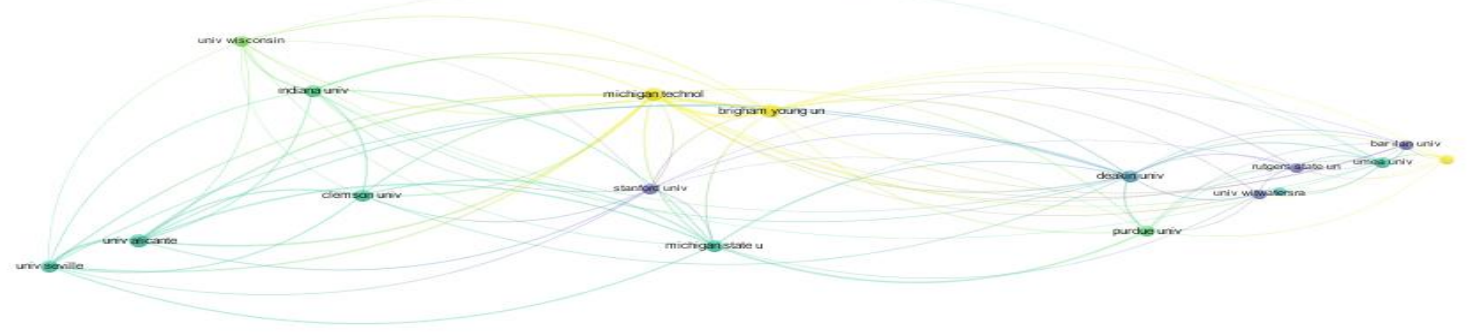

Figure 13. Examination of publications according to institutions and years

As seen in Figure 13, the distribution of publications from bibliographically coupled institutions in the field by years is represented by different colors. According to this, "Universitas Pendidikan Indonesia", "Brigham Young University", and "Michigan Technological University" have come to the fore among the universities that have published in the field in recent years.

\section{Bibliographic couplings of authors}

The bibliographic coupling analysis results of the authors publishing in the field are visualized in Figure 14 and Figure 15. Authors with at least 5 publications out of 1068 bibliographically coupled authors were selected as the threshold value and
20 authors who reached this threshold were included in the analysis. Accordingly, the three strongest authors in the bibliographic coupling were determined as Kashefi H., Yusof Y. M., İsmail Z., who had the same TLS value (786). According to the bibliographic coupling analysis, the authors ranked in the top five are presented in Table 5 with their publication numbers, citation numbers, and TLS values.

Table 5. Bibliographic Couplings of Authors

\begin{tabular}{llll}
\hline Authors & $\begin{array}{l}\text { Number of } \\
\text { publications }\end{array}$ & $\begin{array}{l}\text { Number of } \\
\text { citations }\end{array}$ & TLS \\
\hline Kashefi, Hamidreza & 5 & 21 & 786 \\
Yusof, Yudariah M. & 6 & 21 & 786 \\
Ismail, Zaleha & 5 & 21 & 786 \\
Leatham, Keith R. & 7 & 39 & 776 \\
Peterson, Blake E. & 7 & 39 & 776 \\
\hline
\end{tabular}




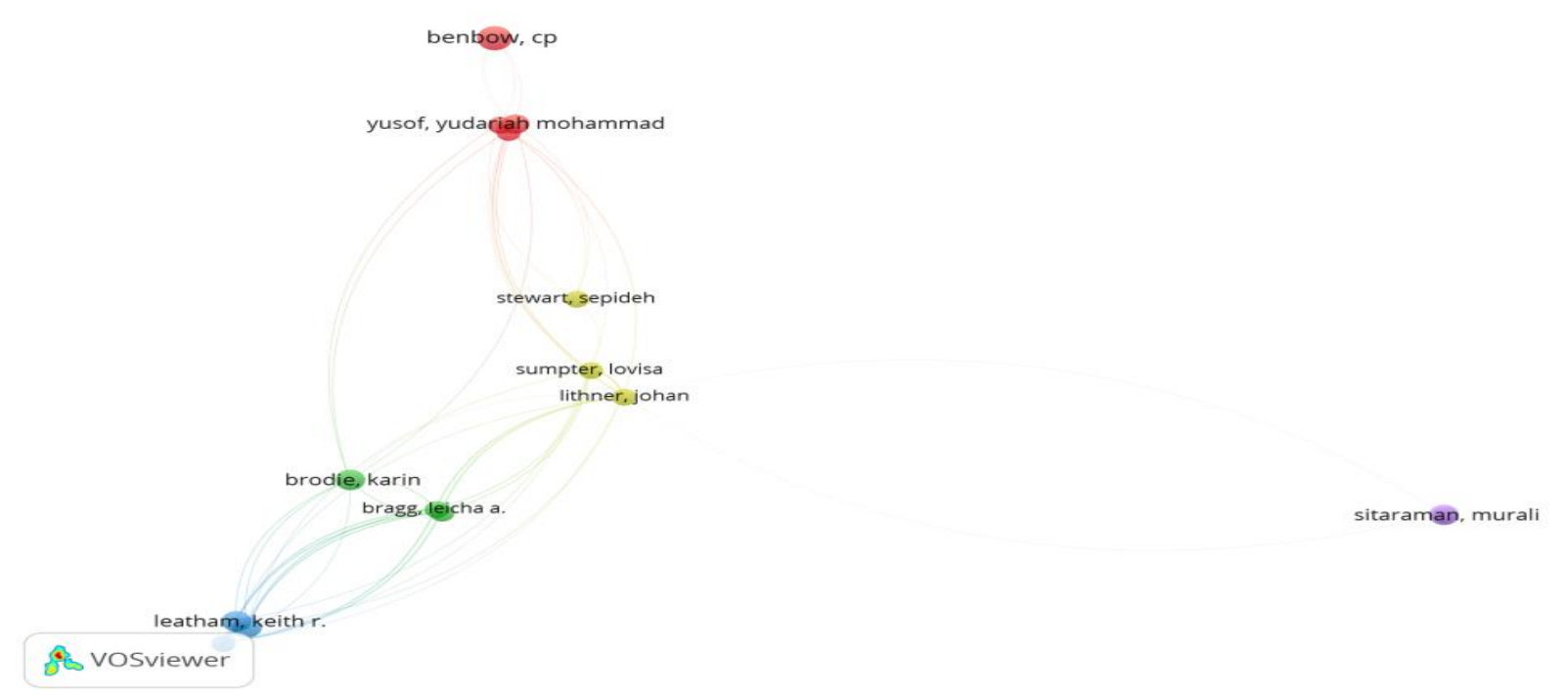

Figure 14.Bibliographic couplings of authors.

As seen in Figure 14, the related authors are represented by 5 different colors in 5 different clusters. In cases where the authors have a lot of connections with each other, they are shown close to each other on the map. Accordingly, the author of Sitaraman M. has no connection with other authors.

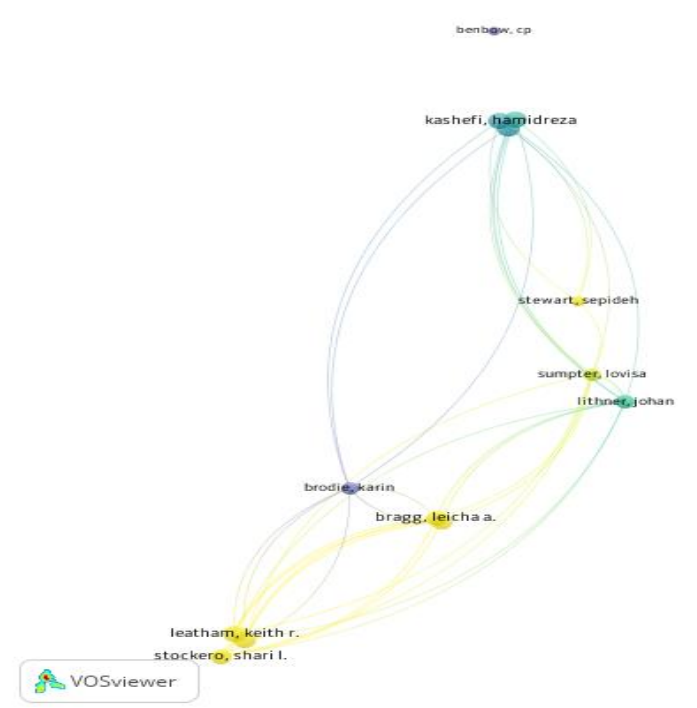

Figure 15. Examination of authors according to publication years.

\section{Discussion and Conclusion}

As seen in Figure 15, the distribution of publications by bibliographically coupled authors according to years is represented by different colors. Accordingly, among the bibliographically coupled authors, Stockero, S., Leatham K.R., Herbert S., and Steward S. are seen to have published the most in recent years.
In this study, the bibliometric analysis method was used to reveal some features of the publications related to mathematical reasoning, to determine the clusters formed as a result of the analyses, to make classifications according to the features that will emerge, and to reveal the trends in the field. For this purpose, a search was made using the advanced searching feature of the WoS 
database. Bibliographic data were obtained, and the obtained data were analyzed and visualized by the software called the VOSviewer. The data were analyzed on the basis of common occurrences of keywords, bibliographic couplings (countries, universities, authors), and co-citations (authors, journals, references).

When the common occurrences of the keywords used by the authors in their publications were examined, researchers determined that the most used keyword for this field is "mathematical reasoning". Researchers also revealed that the concept of mathematical reasoning is used together with the concepts of "mathematical reasoning", "problem solving", and "mathematical thinking" many times. The keywords used by the researchers were gathered under different clusters as a result of their connections with each other. One of the clusters formed included "mathematical reasoning", "argumentation", and "upper secondary school"; while another cluster included "mathematical thinking", "mathematics education", "mathematics", "formative assessment", "creativity", "learning" and "professional noticing".

As a result of the co-citation analysis of the authors, the first three of the most influential authors in the mathematical reasoning field, respectively, Schoenfeld, A. H., Carpenter T. P. and Geary, D. C. has been determined according to the weight of their total connections with others. In addition, NCTM, Mason, and Benbow, among the most commonly cited authors, are also prominent authors in the field.

As a result of the examination of the journals publishing in the field with common citation analysis, the most effective journals were found to be "Journal for Research in Mathematics Education", "Educational Studies in Mathematics", and "Journal of Educational Psychology" on the basis of their links with other sources and the number of common citations. Although it is not one of the first three journals in the field, the "Journal of Mathematics Teacher Education", which is among the most commonly cited journals, has been determined as one of the important journals in the field.

When the joint citation analysis of the references was examined, considering the weight of each publication's links with other publications, the most influential publications were ranked as "Jacobs, Lamb, \& Phillipp (2010)", "NCTM (2000)", "Fennema, Carpenter, Franke, Levi, Jacobs, \& Co. Empson (1996)", "Schoenfeld (1992)" and "Lithner (2008)".

When the bibliographic couplings of the countries were examined, the most influential country as the origin of the publications in the field determined to be the USA, when the ranking is made by considering the weight of the links of each country with other countries. The fact that the first two universities, which are at the forefront of the institutions that are the origin of the publications, are located in the USA confirms this finding. After the USA, Turkey and Swedenare among the most influential countries in the field of mathematical reasoning. According to the bibliographic coupling analysis, the countries that have published the most in the field in recent years have been determined as Indonesia and the People's Republic of China. The fact that one of the prominent institutions in the bibliographic couplings of the institutions of the publications made in recent years is in Indonesia supports this finding.

When the bibliographic couplings of the institutions of the authors publishing in the field of mathematical reasoning were examined, the most effective institutions were "Brigham Young University", "Michigan University", and "Alicante University". The first two universities that come to the fore are also located in the USA. When the number of publications by the institutions publishing in the field is examined, the institutions that have come to the fore in the publications made in the field in recent years were "Universitas Pendidikan Indonesia", "Brigham Young University", and "Michigan Technological University". In the bibliographic coupling of the authors, the fact that one of the top three authors who have come to the fore in publications in recent years works at Brigham 
Young University and the other at Michigan Technological University supports this finding.

Among the authors published in the field, the ones with the strongest bibliographic couplings were found to be "Kashefi H.", "Yusof Y. M.", and "Ismail Z." The two of the three prominent authors were working at universities in Malaysia. When the distribution of publications by bibliographically coupled authors was examined, the most influential authors in recent years were found to be "Stockero, S.", "Leatham K. R.", "Herbert S.", and "Steward S." The first three of the prominent authors who have published in recent years work at universities in the USA.

The fact that the importance of mathematical reasoning has been understood both in learning mathematics and in the process of making sense of mathematics has increased the interest in mathematical reasoning (Bergqvist \& Lithner, 2012; Umay, 2003). A better understanding of the effects of mathematical reasoning on problem solving success (Lithner, 2008) is also one of the factors that increase the interest in the field. Accordingly, understanding what mathematical reasoning is, revealing its subdomains, and identifying activities that will improve reasoning have become extremely important. In this study, data obtained from one of the most prestigious and most preferred databases for accessing scientific information were analyzed. The results of this study, which gives an idea about the tendencies of scientific studies in the fields of mathematical reasoning and mathematical thinking, will contribute to the literature.

\section{References}

Al, U., Soydal, İ., \& Yalçın, H. (2010). Bibliyometrik özellikleri açısından Bilig'in Değerlendirilmesi. Bilig, 55, 1-20.

Ball, D. L., \& Bass, H. (2003). Making mathematics reasonable in school. In (J. Kilpatrick, W. G. Martin, ve D. Schifter Ed.) A research companion to principles and standards for school mathematics, 27-44. Reston, VA: National Council of Teachers of Mathematics.

Bergqvist, T., \& Lithner, J. (2012). Mathematical reasoning in teachers' presentations. The Journal of Mathematical Behavior, 31(2), 252-
269.

https://doi.org/10.1016/j.jmathb.2011.12.002

Bragg, L. A., Herbert, S., Loong, E. Y. K., Vale, C., \& Widjaja, W. (2016). Primary teachers notice the impact of language on children's mathematical reasoning. Mathematics Education Research Journal, 28(4), 523-544. https://doi.org/10.1007/s13394-016-0178-y

Cobo, M. J., López-Herrera, A. G., Herrera-Viedma, E., \& Herrera, F. (2011). Science mapping software tools: Review, analysis, and cooperative study among tools. Journal of the American Society for Information Science and Technology, 62(7), 1382-1402. https://doi.org/10.1002/asi.21525

Garfield, E. (1988). Announcing the SCI Compact disc edition: CD-ROM gigabyte storage technology, novel software, and bibliographic coupling make desktop research and discovery a reality. Current Contents, 22, 3-13.

Hoffman, D. L., \& Holbrook, M. B. (1993). The intellectual structure of consumer research: A bibliometric study of author cocitations in the first 15 years of the Journal of Consumer Research. Journal of Consumer Research, 19(4), 505-517.

Kadarisma, G., Nurjaman, A., Sari, I. P., \& Amelia, R. (2019). Gender and mathematical reasoning ability. Journal of Physics: Conference Series, 1157, 042109. https://doi.org/10.1088/17426596/1157/4/042109

Kurnaz, A. (2018). Examining Effects of Mathematical Problem-Solving, Mathematical Reasoning and Spatial Abilities on Gifted Students' Mathematics Achievement. World Scientific Research, 5(1), 37-43.

https://doi.org/10.20448/journal.510.2018.51. 37.43

Lestari, W. \& Jailani. (2018). Enhancing an Ability Mathematical Reasoning through Metacognitive Strategies. Journal of Physics: Conference Series, 1097, 012117. https://doi.org/10.1088/17426596/1097/1/012117

Lithner, J. (2008). A research framework for creative and imitative reasoning. Educational studies in mathematics, 67(3), 255-276. 
MEB. (2015). Ortaokul Matematik Dersi (5,6,7 Ve 8. Sınıflar) Öğretim Programı. Talim ve Terbiye Kurulu Başkanlığı.

NCTM. (2000). Principles and standards for school mathematics. NCTM.

Noyons, E. C. M., Moed, H. F., \& Van Raan, A. F. J. (1999). Integrating research performance analysis and science mapping. Scientometrics, 46(3), 591-604. https://doi.org/10.1007/BF02459614

Sukirwan, Darhim, \& Herman, T. (2018). Analysis of students' mathematical reasoning. Journal of Physics: Conference Series, 948, 012036. https://doi.org/10.1088/17426596/948/1/012036

Umay, A. (2003). Mathematical reasoning ability. Hacettepe University Journal of Education, 24, 234-243.

White, H. D., \& McCain, K. W. (1998). Visualizing a discipline: An author co-citation analysis of information science, 1972-1995. Journal of the American Society for Information Science. 49(4), 327-355. 